\title{
Visual merchandising and interior design environment impact on consumer apparel buying behaviour with special reference to the apparel stores in Mumbai and Pune
}

\author{
K. Raja Gopal ${ }^{1}$, Vaishali Mahajan ${ }^{2},{\text { Subhasis } \operatorname{Sen}^{3} \text {, Rahul Hiremath }}^{4}$, Richa Priya ${ }^{5}$ \\ $\left\{\right.$ k_rajagopal@scmhrd.edu ${ }^{1}$, vaishali_mahajan@scmhrd.edu ${ }^{2}$, \\ subhasis_sen@scmhrd.edu ${ }^{3}$ \}
}

Symbiosis Centre for Management and Human Resource Development, Symbiosis International $1^{1,2,3,4,5}$

\begin{abstract}
The stores engaged in the pursuit of selling the Apparels are striving hard to acquire and retain the customers amidst stiff competitions. Visual Merchandising is the discipline that deals with the relationship between an object, the context in which it is placed and it's relevant image. It is imperative that the image of the product is such that customers gravitate towards it; this is done by ensuring that its placement context is enticing. There are innumerable apparel stores in the market nowadays. However, what gives each brand an edge is how they market their products; and this is where visual merchandising comes into play. An exploratory research is conducted to examine how the visual merchandising and interior design environment evoke desire to purchase the apparels. The objective of the study is to explore how the apparel buying behaviour is influenced by the visual merchandising. Through extensive literature review it has been found that the most suitable dependent variable would be impulse purchase behaviour. A total of 150 respondents were selected from Pune and Mumbai using simple random sampling technique. On analysis of the data through SPSS, the results reveal that floor merchandising, promotional electronic signage, mannequin display are the most statistically significant factors in impacting consumers' impulse purchase behaviour.
\end{abstract}

Keywords: Apparel buying, consumer buying behaviour, impulse purchase behaviour, floor merchandising

\section{Introduction}

India has become the third most attractive market for Apparel industry according to a study done by AT Kearney, which also states that apparel is the second largest category in retail, representing 5.8\% of US\$ 600 billion. (Shiware, 2013). India has the world's largest youth population with more than $50 \%$ of its population below the age of 25 and $65 \%$ of its population below the age of 35. (Wizar,2013). This young population with rapidly rising disposable income is leading the charge in embracing newer designs, brands and technological advancements. Notably, the e-commerce industry's growth of US\$ 125 billion is single-handedly being driven by this young population and has emerged as a very important channel for apparel industry. This in turn has brought in significant behavioural changes in the purchase patterns of the young population on account of exposure to global trends and increasing cosmopolitanism of Indian 
cities. Since a person's identity is closely linked with clothing and footwear which links to status, class and self-actualization, it should conform to particular city's social norms. It has been observed in previous research that tendency to conform to cultural values of a society is as strong as before irrespective of the effects of globalisation (Corbu, 2009). Previous studies have identified attributes such as price, brand, design and quality having significant influence on consumers' evaluations of apparel products (Hines and Swinkler, 2006). However, with changing times, advent of e-commerce and organised retail, the importance of each attributes does not remain the same and there is a potential for new attributes to influence the preferences of customer. Similarly, consumers in different cities within India may have different preferences of purchasing and product attributes.(Keane and Erdem, 1996).

\section{Literature Review}

Several researches have been conducted to explain the consumer purchase behaviour. The research conducted by Davies, B. \& Ward, P. (2005) [1], aims to prove the use of facet theory in the field of visual merchandising and its relationship with retail branding. In this study, facet theory was applied to the hypothesized relationships, using Small Spaces Analysis (SSA) which proved to be quite useful as both retail branding and visual merchandising are multivariate in nature. The study performed by Klein, A. \&Baun, D. (2001)[2], was an empirical research focusing on visual merchandising and interior design environment to evoke optimum level of customers' arousal by using electro dermal activity (EDA) as an indicator. EDA is very sensitive and can even indicate the smallest variation in arousal. The study which was done by Singh, M. et al (2015) [3], was carried out at Indore shopping mall, MP where data from about 200 customers was collected through questionnaires. A total of 4 hypotheses were taken into consideration for their impact on the buying decisions of consumers - i.e., Design Layouts, Cleanliness of market premises, Window Display and Promotional Signage. The study proved that all of the above stated factors had a significant impact on the customer preference (dependent variable). The research work ofOpris, M. \&Bratucu, G. (2013) [4], was undertaken to explore the intricacies and creativity implemented by various retail stores in window display art in order to build an eye-catching window. The researchers Law, D. et al. (2012) [5],adopted a qualitative method of data collection through focus group interviews involving eight groups. It was found that ideal female image in fact generated a negative response because many customers could not relate to the "flawless figure" of the mannequin and were unsure of how would they look in the displayed lingerie. In terms of product nature, it was found that as compared to outerwear, Chinese women found it embarrassing to witness public displays of intimate apparels. The study concluded that perceived localness is important for visual merchandising of intimate apparels.

The study by Karbasivar, A. \&Yarahmadi, H. (2011) [6], aimed to understand the relationship between consumer buying behavior(with regard to retail apparels outlets) and four external cues namely window displays, credit cards, cash discount and free products. The study was conducted using $n=275$ sample size in Iran and used the survey method to collect responses from shoppers at a mall. The results found that two of the major external cues that indicated more impulse buying behaviour were ever there is cash discount and in store window displays of any form. 
The main objective of this study by Pillai R. et al (2011)[7], stems from the belief that the selling of a product is incomplete without communicating its image. Hence, it aims to find out the extent to which visual merchandising leads to a potential purchase. The findings of the research indicates that price sensitive segment chooses to buy visually appealing branded products. On the part of the merchandisers, the study proved that visual appeal was imperative and that illumination was the most preferred factor by them. Schmid Mast et al. (2009) [8], found that social status of an individual too has influence on his/her susceptibility to interpersonal influence. Consumers' who prefer uniqueness most likely don't place importance to normative influence. This quality helps these consumers to assert their uniqueness during their shopping experience. Mandhachitara and Piamphongsant (2008) [9] has described that things like fashion clothing help in self-construal and also in asserting affiliation with a group.

Depending on the retail preference and patronising the consumers have been grouped into vivid types based on the shopper typologies. (Hartel and Leo 2015) [10]. Thought the Orientation related to the Shopping appears to be simple, it is considered to be the complex mix of economic, social and cultural phenomenon. (Lee and Shim 1999) and it also plays a very special role in performing certain specific activities. ( Gehrt 1998) [11].The shoppers' orientation includes the shoppers with various styles, market behaviour and with vivid preference for the stores of their choice. (Shim and Gehrt ibid 1998) [11]. The shoppers exhibit the variation in the shopping orientation depending on their persona characteristics' and personalities (Bae 2004).

The conceptual model related to the Buying proposed by Radha Krishna (2007) [12] indicated the factors that leads to the a particular behaviour of buyer which is predominantly based on the demographic and the marketing factor.

\begin{tabular}{|c|l|}
\hline Constructs & \multicolumn{1}{|c|}{ Papers } \\
\hline Mannequins & $\begin{array}{l}\text { Kim, J. (2003), Law, D. et al. (2012),Tammy, R. et al (2010), } \\
\text { Mehta N. \&Chugan, P. (2013),Opris, M. \&Bratucu, G. } \\
\text { (2013),Vinamra et al., (2012), Singh, M. et al (2015) }\end{array}$ \\
\hline $\begin{array}{c}\text { Floor } \\
\text { Merchandising }\end{array}$ & $\begin{array}{l}\text { Kim, J. (2003), Mehta, N. \&Chugan, P. (2013), Wu, J. et } \\
\text { al(2013),Vinamra et al., (2012) }\end{array}$ \\
\hline $\begin{array}{c}\text { Promotional } \\
\text { Signage }\end{array}$ & $\begin{array}{l}\text { Kim, J. (2003),Mehta, N. \&Chugan, P. (2013),Singh, M. et al } \\
\text { (2015) }\end{array}$ \\
\hline $\begin{array}{c}\text { Window Display } \\
\text { Krajapati, S.\&Rathod, K. (2013), Kim, J. (2003), } \\
\text { Karbasivar, A.\&Yarahmadi, H. (2011),Mehta, N. } \\
\text { \&Chugan, P. (2013),Opris,M.\&Bratucu, G. (2013) }\end{array}$ \\
\hline $\begin{array}{c}\text { Illumination } \\
\text { Layout }\end{array}$ & $\begin{array}{l}\text { Prajapati, S.\&Rathod, K. (2013), Pillai R. et al } \\
\text { T. (2013) Opris,M.\&Bratucu, G. (2013),Madhavi, S. \&Leelavati }\end{array}$ \\
\hline Colour & $\begin{array}{l}\text { Wu, J.et al (2013),Opris, M. \&Bratucu, G. } \\
\text { (2013),Madhavi, S. \&Leelavati T. (2013) }\end{array}$ \\
\hline Theme & Madhavi, S. \&Leelavati T. (2013) \\
\hline Landscaping & Mower, J. et al, (2012) \\
\hline Cleanliness & Singh, M. et al (2015) \\
\hline
\end{tabular}

Table 1 The various constructs that were derived from the literature. 


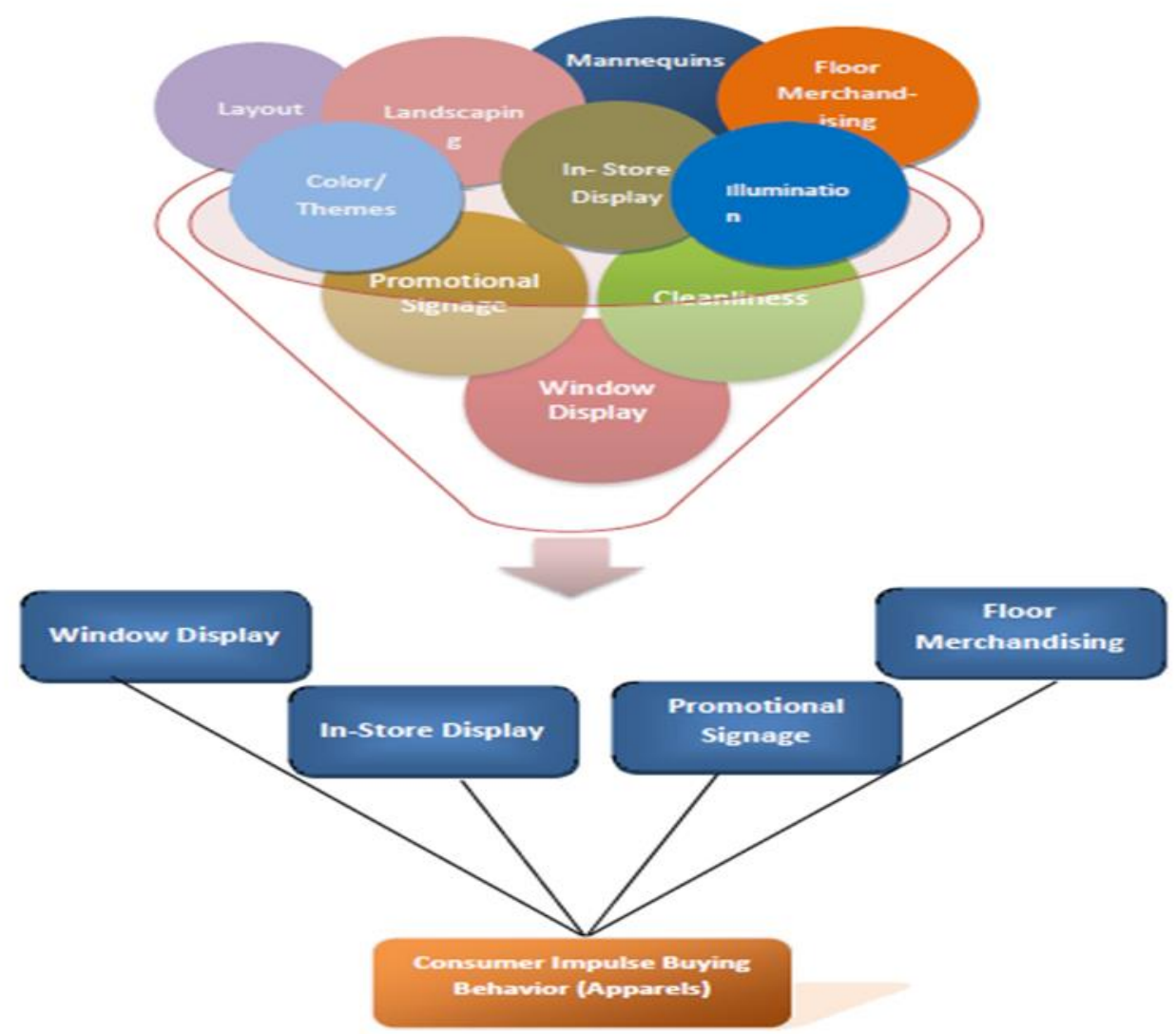

Fig.1 shows the various constructs that were derived from the literature.

\section{Hypothesis Of The Study}

Based on the above literature the following hypotheses were derived:

- H1: Customers who buy on impulse are influenced by mannequin displays

- H2: Customers who buy on impulse are influenced by window displays

- H3: Customers who buy on impulse are influenced by promotional signage

- H4: Customers who buy on impulse are influenced by floor merchandising

\section{Objective Of The Study}

- To study the visual merchandising impact on the consumer's apparel purchasing behaviour 
- To study specifically the impact of, in store mannequin display, promotional signage, window display, and floor merchandizing on consumer purchase behaviour.

\section{Methodology}

In this study, survey method is adopted and a cross-sectional descriptive research approach is followed as the variables undertaken for study cannot be attempted to any way of manipulation since they are of intrinsic in nature. These variables are studied using descriptive research. As indicated by Shuttleworth,2008) the survey method ensures the collection of the relevant quantitative data to understand the consumers purchase decision making style which helps the researcher to make an approximation on the test of causality(Bush \& Burns 2007). The research data was collected through the Personal interview method. A combination of judgemental and convenience sampling methods were adopted to select the 150 respondents from Mumbai and Pune region.

The data collected from the respondents were cleansed to ensure that are no missing or invalid responses. Next the KMO and Bartlettees test, test of communalities, factor analysis and construct validity tests were performed. This showed the grouping of the factors and indicated that, mannequins, window display, promotional signage and floor merchandising are clearly four distinct factors. The coded items are shown below before proceeding with the SPSS analysis.

\begin{tabular}{|c|l|}
\hline Code & \multicolumn{1}{c|}{ Item } \\
\hline F2 & $\begin{array}{l}\text { The manner in which the product is displayed in the store has an impact on } \\
\text { my buying decisions }\end{array}$ \\
\hline F3 & While passing by I get fixed to dresses which are eye catching \\
\hline F4 & $\begin{array}{l}\text { Product assortment, product placements and props have a high impact on my } \\
\text { buying decisions }\end{array}$ \\
\hline F5 & I look for clothing close to me especially when I am walking on the isle \\
\hline I1 & Viewing Promotion sign results in me buying more than i intended to buy \\
\hline I2 & $\begin{array}{l}\text { when I find the window visual display attractive of a store I end up in buying } \\
\text { more }\end{array}$ \\
\hline I3 & $\begin{array}{l}\text { I find myself spending more than intended on clothing items that are paired } \\
\text { together }\end{array}$ \\
\hline M1 & Any new style of apparels displayed in the store makes me by more. \\
\hline M2 & I tend to buy the apparels displayed on the mannequin \\
\hline M3 & $\begin{array}{l}\text { The apparels displayed on the mannequin triggers the idea in me to buy } \\
\text { the apparel. }\end{array}$ \\
\hline M4 & store displays triggers me to make apparel purchasing decision \\
\hline Plii & Any attractive sale sign on my vicinity results in unintended apparel buying \\
\hline Pliii & $\begin{array}{l}\text { Any type of sales promotional offer signs displayed in the store temts me to } \\
\text { buy the apparel }\end{array}$ \\
\hline Pliv & when I enter a store I look for promotional offering signage \\
\hline Plv & Any special promotion sign makes me to look for the apprels \\
\hline WDi & window display of the stores draws my attention \\
\hline WDii & $\begin{array}{l}\text { I am attracted to enter a store if I notice promotional offers at the store } \\
\text { entrance }\end{array}$ \\
\hline
\end{tabular}




\begin{tabular}{|c|l|}
\hline WDiv & $\begin{array}{l}\text { On looking at the window display of a shop i am able to gauge the type of } \\
\text { store and its sales promotional offerings }\end{array}$ \\
\hline WDv & The visual display of a shop front attracts me to enter the store \\
\hline
\end{tabular}

Table 2 Grouping of the factors

\section{Interpretation of test for communalities}

Communalities indicate the amount of variance in each variable that is accounted for. In the test for communalities in SPSS, it is found that M1 and M4 has values less than 0.5. All the other questions gave an extraction output greater than 0.5 . The principal method is used for extraction. All values which are less than 0.5 are removed.

\begin{tabular}{|l|r|r|}
\hline & Initial & Extraction \\
\hline WDi & 1.000 & .616 \\
WDii & 1.000 & .721 \\
WDiii & 1.000 & .693 \\
WDiv & 1.000 & .640 \\
M1 & 1.000 & .41 \\
M2 & 1.000 & .721 \\
M3 & 1.000 & .698 \\
M4 & 1.000 & .42 \\
F1 & 1.000 & 1 \\
F2 & 1.000 & .772 \\
F3 & 1.000 & .783 \\
F4 & 1.000 & .748 \\
Pli & 1.000 & .575 \\
Plii & 1.000 & .673 \\
Pliii & 1.000 & .679 \\
Pliv & 1.000 & .600 \\
I1 & 1.000 & .687 \\
I2 & 1.000 & .767 \\
I3 & 1.000 & .771 \\
I4 & 1.000 & .761 \\
\hline
\end{tabular}

Table 3 Test for communalities

Now, all questions have communality factor $>0.5$ 
Hence factor analysis is performed,

Factor Analysis Interpretation

\begin{tabular}{|c|c|c|c|c|c|c|c|c|c|}
\hline \multirow[t]{2}{*}{$\begin{array}{l}\text { Compone } \\
\text { nt }\end{array}$} & \multicolumn{3}{|c|}{ Initial Eigenvalues } & \multicolumn{3}{|c|}{$\begin{array}{l}\text { Extraction Sums of Squared } \\
\text { Loadings }\end{array}$} & \multicolumn{3}{|c|}{$\begin{array}{l}\text { Rotation Sums of Squared } \\
\text { Loadings }\end{array}$} \\
\hline & Total & $\begin{array}{l}\% \text { of } \\
\text { Variance }\end{array}$ & $\begin{array}{l}\text { Cumulativ } \\
\text { e } \%\end{array}$ & Total & $\begin{array}{l}\% \quad \text { of } \\
\text { Variance }\end{array}$ & $\begin{array}{l}\text { Cumulativ } \\
\text { e } \%\end{array}$ & Total & $\begin{array}{l}\% \text { of } \\
\text { Variance }\end{array}$ & $\begin{array}{l}\text { Cumulativ } \\
\text { e } \%\end{array}$ \\
\hline $\mathrm{i}$ & 5.564 & 30.913 & 30.913 & 5.564 & 30.913 & 30.913 & 3.046 & 16.923 & 16.923 \\
\hline ii & 2.527 & 14.038 & 44.951 & 2.527 & 14.038 & 44.951 & 3.046 & 16.922 & 33.844 \\
\hline iii & 1.954 & 10.858 & 55.809 & 1.954 & 10.858 & 55.809 & 2.482 & 13.791 & 47.636 \\
\hline iv & 1.670 & 9.278 & 65.088 & 1.670 & 9.278 & 65.088 & 2.457 & 13.648 & 61.283 \\
\hline $\mathrm{v}$ & 1.137 & 6.319 & 71.407 & 1.137 & 6.319 & 71.407 & 1.822 & 10.124 & 71.407 \\
\hline vi & .749 & 4.162 & 75.569 & & & & & & \\
\hline vii & 612 & 3.399 & 78.968 & & & & & & \\
\hline viii & .584 & 3.246 & 82.215 & & & & & & \\
\hline ix & 499 & 2.771 & 84.985 & & & & & & \\
\hline $\mathrm{x}$ & 472 & 2.624 & 87.609 & & & & & & \\
\hline $\mathrm{xi}$ & 394 & 2.187 & 89.796 & & & & & & \\
\hline xii & 370 & 2.057 & 91.853 & & & & & & \\
\hline xiii & 322 & 1.787 & 93.640 & & & & & & \\
\hline xiv & .290 & 1.614 & 95.254 & & & & & & \\
\hline$x v$ & .254 & 1.410 & 96.664 & & & & & & \\
\hline xvi & .214 & 1.190 & 97.854 & & & & & & \\
\hline xvii & .202 & 1.121 & 98.975 & & & & & & \\
\hline xviii & .185 & 1.025 & 100.000 & & & & & & \\
\hline
\end{tabular}

Table 5. Variance Explained 
Principal Component Analysis method of extraction

Though the ideal percentage should be $75 \%$ the computed value is $71.4 \%$

\begin{tabular}{|c|c|c|c|c|c|}
\hline & \multicolumn{5}{|c|}{ Component } \\
\hline & $\mathrm{i}$ & ii & iii & iv & $\mathrm{v}$ \\
\hline WDi & & & .738 & & \\
\hline WDii & & & .752 & & \\
\hline WDiii & & & .804 & & \\
\hline WDiv & & & .720 & & \\
\hline M2 & & & & & .750 \\
\hline M3 & & & & & .735 \\
\hline $\mathrm{F} 1$ & .826 & & & & \\
\hline $\mathrm{F} 2$ & .847 & & & & \\
\hline F3 & .830 & & & & \\
\hline F4 & .707 & & & & \\
\hline Pli & & & & .771 & \\
\hline Plii & & & & .725 & \\
\hline Pliii & & & & .717 & \\
\hline Pliv & & & & .753 & \\
\hline I1 & & .843 & & & \\
\hline $\mathrm{I} 2$ & & .831 & & & \\
\hline $\mathrm{I} 3$ & & .852 & & & \\
\hline I4 & & .769 & & & \\
\hline
\end{tabular}

Table 6 Rotated Component Matrix 
The result of the Rotated Component Matrix clearly indicates that Mannequins, Window display, Promotional Signage and Floor Merchandising are the 4 different factors that affect impulse purchase behaviour.

\section{Construct Validity}

The purpose of performing the Construct validity test using Scale Composite Reliablity(SCR),Standard Factor Loadings(SFL),Chronbach's Alpha test of Reliabilty, Discriminat Validity and Average Variance Extracted(AVE). These tests are performed to establish on the fact regarding how well the research data could be transformed into a useable research data.

\begin{tabular}{|c|c|c|c|c|c|c|}
\hline Factors & Factor & $\begin{array}{c}\text { 1- } \\
\text { Square }\end{array}$ & SCR & $\begin{array}{c}\text { Square } \\
\text { of }\end{array}$ & AVE & Interpretation \\
\hline & & FL & & FL & & \\
\hline \multirow{5}{*}{$\begin{array}{l}\text { Window } \\
\text { Display }\end{array}$} & 0.74 & 0.46 & 0.85 & 0.54 & 0.58 & \multirow{5}{*}{ Reliable } \\
\hline & 0.79 & 0.38 & & 0.62 & & \\
\hline & 0.8 & 0.35 & & 0.65 & & \\
\hline & 0.72 & 0.48 & & 0.52 & & \\
\hline & 3.05 & 1.67 & & 2.33 & & \\
\hline \multirow{3}{*}{$\begin{array}{c}\text { Mannequin } \\
\text { Display }\end{array}$} & 0.75 & 0.44 & 0.71 & 0.56 & 0.55 & \multirow{3}{*}{ Reliable } \\
\hline & 0.74 & 0.46 & & 0.54 & & \\
\hline & 1.49 & 0.9 & & 1.1 & & \\
\hline \multirow{5}{*}{$\begin{array}{c}\text { Floor } \\
\text { Merchandisin } \\
\mathrm{g}\end{array}$} & 0.83 & 0.32 & 0.88 & 0.68 & 0.65 & \multirow{5}{*}{ Reliable } \\
\hline & 0.85 & 0.28 & & 0.72 & & \\
\hline & 0.83 & 0.31 & & 0.69 & & \\
\hline & 0.71 & 0.5 & & 0.5 & & \\
\hline & 3.21 & 1.41 & & 2.59 & & \\
\hline \multirow{5}{*}{$\begin{array}{l}\text { Promotional } \\
\text { Sinage }\end{array}$} & 0.77 & 0.4 & 0.83 & 0.6 & 0.55 & \multirow{5}{*}{ Reliable } \\
\hline & 0.73 & 0.47 & & 0.53 & & \\
\hline & 0.72 & 0.49 & & 0.51 & & \\
\hline & 0.75 & 0.43 & & 0.57 & & \\
\hline & 2.97 & 1.8 & & 2.2 & & \\
\hline \multirow{3}{*}{$\begin{array}{l}\text { Impulse } \\
\text { Purchase }\end{array}$} & 0.84 & 0.29 & 0.89 & 0.71 & 0.68 & \multirow{3}{*}{ Reliable } \\
\hline & 0.83 & 0.31 & & 0.69 & & \\
\hline & 0.85 & 0.27 & & 0.73 & & \\
\hline
\end{tabular}




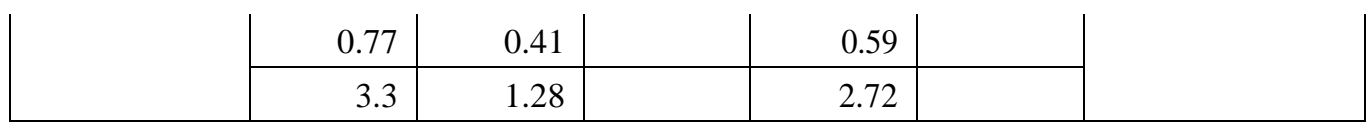

Table 7 Reliability and Average Variance Extracted

- As seen in the table above, all the factor loading values are greater than 0.5 hence indicating reliability.

- All the SCR values are greater than 0.70, is a pure evidence that the items have got high level of internal consistency relatively.

\section{Discriminant Validity}

Discriminant validity is a test which is performed to ascertain the impact of the visual merchandising factors on impulsive apparel buying behaviour of the customers.

\begin{tabular}{|c|c|c|c|c|c|}
\hline & WD & M & $\mathrm{F}$ & $\mathrm{P}$ & I \\
\hline WD & 0.762787 & $.264^{* *}$ & $.314^{* *}$ & $.214^{*}$ & 0.153 \\
\hline M & $.264^{* *}$ & 0.742564 & $.506^{* *}$ & $.243^{* *}$ & $.393^{* *}$ \\
\hline F & $.314^{* *}$ & $.506^{* *}$ & 0.804311 & $.278^{* * *}$ & $.255^{* *}$ \\
\hline $\mathrm{P}$ & $.214^{*}$ & $.243^{* *}$ & $.278^{* * *}$ & 0.742024 & $.400^{* * *}$ \\
\hline I & 0.153 & $.393^{* *}$ & $.255^{* *}$ & $.400^{* * *}$ & 0.824586 \\
\hline
\end{tabular}

Table 8 Discriminant validity

- The values in the table are the Pearson Correlation values for the various factor combinations depicted.

- The correlation was run after calculating the average of each factor with respect to each response.

- The Pearson values are all less than the highlighted values (square root of AVE) which are an evidence of nil relationship among the factors

\section{Cronbach's Alpha}

In this study the Chronbaches alpha test is performed on the 5 (1-Dependendent variable which is Impulsive Buying Behaviour) and the other 4 dependable variable used in our study includes the 4 Visual Merchandising promotional factors.

The results of our study are as follows -

Reliability Test (Cronbach's Alpha Test) 
(1) Impulse Buying Behavior

\begin{tabular}{|c|l|c|}
\hline $\begin{array}{l}\text { Cronbach's } \\
\text { Alpha }\end{array}$ & $\begin{array}{l}\text { Cronbach's Alpha } \\
\text { Based on } \\
\text { Standardized } \\
\text { Items }\end{array}$ & N of Items \\
\hline 0.881 & \multicolumn{1}{|c|}{0.881} & 4 \\
\hline
\end{tabular}

Table 9 Statistics with regard to the Reliablity

Since the value of Chronbach "s alpha test is 0.881 for impulse buying behaviour i.e. is a straight evidence that the item has got high level of the internal consistency relatively, since the value is way above 0.7 .

(2) The Aspect of Window Display

\begin{tabular}{|c|c|c|}
\hline $\begin{array}{c}\text { Cronbach's } \\
\text { Alpha }\end{array}$ & $\begin{array}{c}\text { Cronbach's Alpha } \\
\text { Based on } \\
\text { Standardized } \\
\text { Items }\end{array}$ & N of Items \\
\hline 0.79 & 0.79 & 4 \\
\hline
\end{tabular}

Table 10 Reliability Statistics

Since the value of Chronbaches alpha test is 0.790 for window display, is pure evidence that the item has got high level of the internal consistency relatively, since the value is way above 0.7 .

(3) In regard to the In-Store/Mannequin Display

\begin{tabular}{|c|c|c|}
\hline $\begin{array}{c}\text { Cronbach's } \\
\text { Alpha }\end{array}$ & $\begin{array}{c}\text { Cronbach's Alpha } \\
\text { Based on } \\
\text { Standardized } \\
\text { Items }\end{array}$ & N of Items \\
\hline 0.825 & 0.827 & 2 \\
\hline
\end{tabular}

Table 11 Cronbach's Alpha

Since the value of Chronbach ${ }^{\text {ee }}$ alpha test is 0.825 for In-Store/Mannequin Display, is obvious evidence that the item has got high level of the internal consistency relatively, since the value is way above 0.7 .

(4) With respect to Floor Merchandising

\begin{tabular}{|c|c|r|}
\hline $\begin{array}{c}\text { Cronbach's } \\
\text { Alpha }\end{array}$ & $\begin{array}{c}\text { Cronbach's Alpha } \\
\text { Based on } \\
\text { Standardized } \\
\text { Items }\end{array}$ & N of Items \\
\hline 0.859 & 0.859 & 4 \\
\hline
\end{tabular}

Table 12 Cronbach's Alpha 
Since the value of Chronbach ${ }^{\text {ee }}$ alpha test is 0.859 for Floor Merchandising, is bright evidence that the item has got high level of the internal consistency relatively, since the value is way above 0.7 .

\section{(5) Regarding the Promotional Signage}

\begin{tabular}{|c|c|c|}
\hline $\begin{array}{c}\text { Cronbach's } \\
\text { Alpha }\end{array}$ & $\begin{array}{c}\text { Cronbach's Alpha } \\
\text { Based on } \\
\text { Standardized } \\
\text { Items }\end{array}$ & N of Items \\
\hline 0.774 & 0.777 & 4 \\
\hline
\end{tabular}

Table 13 Cronbach's Alpha

Since the value of Chronbach ${ }^{\text {ee }}$ alpha test is 0.774 Promotion Signage, is a clear evidence that the item has got high level of the internal consistency relatively, since the value is above 0.7 .

Hence we see that for each of the 5 variables the value of Chronbach's alpha test is more than 0.7 and thus we have an acceptable and strong reliability to go ahead with our research.

\begin{tabular}{|c|c|c|c|c|}
\hline \multicolumn{5}{|c|}{ Model Summary $^{\mathbf{b}}$} \\
\hline Model & $\mathrm{R}$ & R Square & $\begin{array}{c}\text { Adjusted } \\
\text { R Square }\end{array}$ & $\begin{array}{c}\text { Error of } \\
\text { the } \\
\text { Estimate }\end{array}$ \\
\hline 1 & $.411^{\mathrm{a}}$ & 0.292 & 0.227 & 0.76392 \\
\hline
\end{tabular}

Table 14 Regression Analysis

a) Predictors: (Constant), $A v g P, A v g W D, A v g M, A v g F$

b) Dependent Variable: AvgI

The $\mathrm{R}$ square value in the output shows 0.253 . The value of $25.3 \%$ of the variance reported in the dependent variable (impulse purchase behaviour) can be explained by the independent variables; which are the four visual merchandising factors. This indicates that there is low amount of variance that is being explained by the data collected. Although the $\mathrm{R}$ square value is low this is expected from research that studies could be due to the psychological aspects of humans.

ANOVA ${ }^{a}$

\begin{tabular}{|c|c|c|c|c|c|c|}
\hline Model & & $\begin{array}{c}\text { Sum of } \\
\text { Squares }\end{array}$ & Df & $\begin{array}{c}\text { Mean } \\
\text { Square }\end{array}$ & F & Sig. \\
\hline & Regression & 23.173 & 4 & 5.543 & 9.50 & $.000^{\mathrm{b}}$ \\
\hline 1 & Residual & 65.36 & 112 & 0.584 & & \\
\hline & Total & 87.533 & 116 & & & \\
\hline
\end{tabular}

Table 15 Anova 
a) Variable which are dependent: AvgI

b) The Predictors AvgP, AvgWD, AvgM, AvgF are Constant.

In the ANOVA table we can see the significance value is $<0.05$ hence this shows us that the regression model is a good fit of the data. There is a good fit of the data in the regression model as the ANOVA calculation has a level of significance value which is $<0.05$

\begin{tabular}{|c|c|c|c|c|c|c|c|}
\hline Model & \multicolumn{2}{|c|}{$\begin{array}{c}\text { Unstandardized } \\
\text { Coefficients }\end{array}$} & $\begin{array}{c}\text { Standardized } \\
\text { Coefficients }\end{array}$ & T & \multicolumn{2}{|c|}{ Sig. } & \multicolumn{2}{|c|}{$\begin{array}{c}\text { 95.0\% Confidence } \\
\text { Interval of B }\end{array}$} \\
\hline & B & $\begin{array}{c}\text { Std. } \\
\text { Error }\end{array}$ & Beta & & & $\begin{array}{c}\text { Lower } \\
\text { Bound }\end{array}$ & $\begin{array}{c}\text { Upper } \\
\text { Bound }\end{array}$ \\
\hline (Constant) & 1.313 & 0.557 & & 2.356 & 0.02 & 0.209 & 2.418 \\
\hline AvgWD & -0.001 & 0.126 & -0.001 & - & 0.992 & -0.251 & 0.249 \\
\hline AvgM & 0.272 & 0.084 & 0.311 & 3.235 & 0.002 & 0.105 & 0.438 \\
\hline AvgF & 0.01 & 0.116 & 0.009 & 0.089 & 0.929 & -0.22 & 0.241 \\
\hline AvgP & 0.346 & 0.093 & 0.322 & 3.735 & 0 & 0.162 & 0.53 \\
\hline
\end{tabular}

Table 16 Coefficients

a) Dependent Variable: $A v g I$

b) The significance values show that only AvgM (Mannequin Display) and AvgP (Promotional Signage) are statistically significant independent variables.

With the coefficients we can form the following regression equation:

$$
Y(A v g I)=1.313+0.272(A v g M)+0.346(A v g P)
$$

\section{Conclusion}

The aim of our study was to see the impact of visual merchandising on consumer purchase behaviour with reference to apparel stores. The factors of visual merchandising that we studied were window display, in store/mannequin display, floor merchandising and promotional signage.

Though all the four factors of visual merchandising acts as four independent factors while impacting the impulse buying behaviour of apparel, we conclude from the research findings that that all these four factors have an impact on the consumer purchase behaviour ins some form or the other.

However out of these four factors, there were two, Mannequin Display and Promotional Signage factors of visual merchandising that are statistically significant when it comes to impulse apparel purchase behaviour. 
This suggests that consumers are most influenced to buy a certain product if they find the mannequin display attractive. The promotional signage is also a driving factor to positively influence an individual's to buy a product. Hence, we can firmly conclude that managerial attention should be focused on these two factors in order to increase impulse purchases. They should make their mannequin displays more attractive and the promotional signage more enticing for the consumers. This is likely to increase the sales of their product on impulse.

This is interesting as it furthers the already existing research, by Kim, J. (2003) which states both promotional signage and mannequin display are significantly related to impulse buying behaviour. Much like our research the same paper shows that window displays and floor merchandising also affect the behaviour, however, this is fairly lower when compared to the former two. The paper by Mehta, N. \&Chugan, P. (2013) states that floor merchandising is as important a factor as the other two. Our research, like the research done by Kim, J. (2003), contradicts this.

\section{References}

[1] Davies, B. \& Ward, P., 2005. Exploring the connections between visual merchandising and retail branding: An application of facet theory. International Journal of Retail \& DistributionManagement, 33 (7), pp. 505-513.

[2] Klein, A. \&Baun, D., 2001. The Role of Customers= Arousal For Retail Store - Results From an Experimental Pilot Study Using Electrodermal Activity As Indicator. Advances inConsumer Research 28, pp. 412-419.

[3] Singh, M. et al, 2015. Customer Preference Analysis towards Visual Merchendsing. International Journal of Science, Technology and Management, 4 (4), pp. 150-159.

[4] Opris, M. \&Bratucu, G., 2013. Visual Merchandising Window Display. Bulletin of theTransylvania University of Brasov, 6 (55), pp. 51-56.

[5] Law, D. et al., 2012. How does visual merchandising affect consumer affective responses?: An intimate apparel experience. European Journal of Marketing, 46 (2), pp. 112 -133 .

[6] Karbasivar, A. \&Yarahmadi, H., 2011. Evaluating effective factors on consumer impulse buying behaviour. Asian Journal of Business Management Studies, 2 (4), pp. 174 - 181.

[7] Pillai R. et al, 2011. Design, effectiveness and role of Visual Merchandising in creating Customer Appeal .MPRA Munich Personal RePEc Archive.

[8] Schmid Mast, M., Jonas, K., \& Hall, J. A. (2009). Give a person power and he or she will show interpersonal sensitivity: The phenomenon and its why and when. Journal of personality and social psychology, 97(5), 835.

[9] Piamphongsant, T., \&Mandhachitara, R. (2008). Psychological antecedents of career women's fashion clothing conformity. Journal of Fashion Marketing and Management: An International Journal, 12(4), 438-455.

[10] Leo, C., Bennett, R., \&Härtel, C. E. (2005). Cross-cultural differences in consumer decision-making styles. Cross Cultural Management: An International Journal, 12(3), 32-62. [11] Gehrt, K. C., \& Shim, S. (1998). A shopping orientation segmentation of French consumers: Implications for catalog marketing. Journal of interactive Marketing, 12(4), 3446. 
[12] Krishna, G. R., \&Shylajan, C. S. (2007). Determinants of Habitual Buying Behavior: A Study of Branded Apparels. The ICFAI Journal of Marketing Management, 6(3), 6-21.

[13] Kim, J., (2003). College Students' apparel impulse buying behaviour in relation to visualmerchandising. Master of Science. The University of Georgia.

[14] Madhavi, S. \&Leelavati T., 2013. Impact of visual merchandising on consumer behaviour towards women apparel. International Journal of Management Research and BusinessStrategy, 2 (4), pp. 61-72.

[15] Mehta, N. \&Chugan, P., 2013. The impact of Visual Merchandising on Impulse Buying Behaviour of Consumer: A case from Central Mall of Ahmedabad India. Universal Journalof Management, 1 (2), pp. 76-82.

[16] Mower, J. et al, 2012. Exterior atmospherics and consumer behaviour: Influence on landscaping and window display. Journal of Marketing Management, 16 (4), pp. 442 - 453.

[17] Prajapati, S. \&Rathod, K., 2013. A study on Impulse Buying Behaviour of College Students for Branded Apparels in Ahmedabad City. International Journal of Management, 4 (6), pp. $128-134$.

[18] Tammy, R. et al,2010. Shopping Behaviour and the Involvement Construct. Journal ofFashion Marketing and Management ,14 (4), pp. 562-575.

[19] Vinamra et al., 2012. Impact of Visual Merchendising on Consumer Behaviour towards Women "s Apparel. International Journal of Research in Management, 2 (5), pp. 106 - 117 [20] Wu, J. et al, 2013. Fashion Product Display: An experiment with mockshop investigating colour, visual texture and style coordination. International Journal of Retail \& DistributionManagement, 41 (10), pp. 765-789. 